\title{
Narrativer i konflikt
}

ISRAELS “NYE HISTORIKERE” OG OMSKRIVINGEN AV KRIGEN I 1948

Frem til slutten av I980-tallet var de fleste israeleres oppfatning av krigen i I948 preget av ideologisk historiefortelling i nasjonsbyggingens navn. De "nye historikerne" utfordret de gamle forestillingene og debatten som fulgte rokket ved Israels etablerte maktstrukturer, kollektive hukommelse og selvforståelse.

Trude Strand, doktorgradsstipendiat i historie, Universitetet i Oslo.

"I denne krigen, som i de fleste kriger, gikk den sterkeste part seirende ut." ${ }^{{ }^{I}}$ En slik konklusjon oppfattes vanligvis som lite kontroversiell. Historien om en krig er gjerne historien om at en av partene er sterkere enn den annen og kan feire sin seier etter å ha nedkjempet fienden. I Israel, derimot, har en annen type fremstiling dominert bildet av krigen i i948. Den tradisjonelle sionistiske versjonen forteller om krigen mellom den nyetablerte staten Israel og de omliggende araberstatene som Davids kamp mot Goliat. Ifølge denne versjonen hadde britene ført en politikk som gagnet fienden i perioden som ledet opp til krigen. Sammenlignet med jødene var denne fienden en militær og politisk overmakt. Araberstatene sto samlet i sin målsetning om å hindre den israelske statens overlevelse, og selve jødenes eksistens i området var truet. Israels seier kom dermed uventet, og den palestinske masseflukten som hadde funnet sted før, under og etter den offisielle krigen, var et resultat av arabiske lederes instrukser.

Israels nye historikere utfordret denne fremstillingen av i948. Spørsmålet de stilte var: Hva skjedde egentlig i tiden før, under og etter krigen? Gjennom deres forskning ble tidligere sannheter plukket fra hverandre og nye konklusjoner trukket frem. 88
Dette gjaldt særlig i behandlingen av spørsmål som den jødisk-arabiske militærbalansen, fiendebildet av de omliggende araberstatene, araberstatenes målsetninger med krigen, og sist, men ikke minst, den palestinske masseflukten og starten på det palestinske flyktningproblemet. Temaene de nye historikerne problematiserte er direkte knyttet til krigens hendelsesforløp og resultat. Og grunnlaget for det store skillet mellom "ny" og "gammel" historiefortelling i Israel finnes nettopp i behandlingen av, og konklusjonene rundt disse spørsmålene.

Denne artikkelen ser nærmere på de israelske "myteknekkerne" og betydningen av deres forskning for det israelske samfunnet. En gjennomgang av utvalgte funn setter de nye historikerne opp mot den tradisjonelle sionistiske versjonen. Konflikten som oppsto mellom tidligere oppfatninger og nyere forskning, danner utgangpunktet for en diskusjon av kontroversen knyttet til de nye historikerne og gir svar på hvorfor et knippe israelske forskere sto i sentrum for høylytt akademisk og offentlig debatt flere tiår etter krigens slutt.

\section{Fortiden sett med nye briller}

Israels nye historikere er en løst definert gruppe akademikere som har kastet lys 
over ubehagelige sannheter i Israels historie. ${ }^{2}$ Med Benny Morris, Avi Shlaim og Ilan Pappé i spissen er det på ingen måte en ensartet gruppe. Konklusjonene de ulike historikerne trekker på bakgrunn av egne funn danner det tydeligste skillet. For eksempel plasserer Ilan Pappé israelske militære operasjoner under krigen i I948 i kategorien etnisk rensing i henhold til en plan, mens Benny Morris forholder seg til hendelsene som et resultat av krigen i seg selv. ${ }^{3}$ I tillegg er det store uenigheter rundt metodevalg og forholdet mellom historikerrollen og politisk engasjement. Også her er det Pappé som skiller seg ut fra de andre to gjennom sin relativiserende tilnærming til historiefaget og et uttalt politisk budskap. Mens Morris og Shlaim avfeier politisk motivasjon for sin forskning, sier Pappé at hans virke som akademiker i stor grad er farget av samtidige politiske realiteter og hans eget ideologiske ståsted. ${ }^{4}$

Det som forener troikaen, og har gitt dem navnet "nye historikere", er deres bruk av nye kilder. Kildegrunnlaget i deres forskning stammer i all hovedsak fra dokumenter gjort tilgjengelig $\mathrm{i}$ israelske arkiver fra midten av I980-tallet. De nye historikerne tilhører også en generasjon som ikke selv opplevde krigen om Palestina i I948. Sammen har disse faktorene muliggjort israelsk historiefortelling fra et ståsted som ligger utenfor sionismens varme favn med hensyn til nasjons- og omdømmebygging.5

Startskuddet for den israelske omskrivingen av krigen i I948 smalt først førti år etter krigens slutt, med publiseringen av en artikkel om det palestinske flyktningproblemet skrevet av Benny Morris. ${ }^{6}$ Artikkelen, trykket i det jødisk-amerikanske tidsskriftet Tikkun satte sinnene i kok i israelske akademiske kretser og blant mange jøder i diasporaen.7 Gjennom en rekke publikasjoner i tiden som fulgte, satte Morris og de andre nye historikerne spørsmålstegn ved sentrale påstander og konklusjoner fremsatt i tradisjonell sionistisk historiefortelling.

\section{Militærbalansen: David mot Goliat?}

Var utfallet av krigen i i948 som den bibelske Davids seier over Goliat? I sterk kontrast til den tradisjonelle sionistiske versjonen, peker de nye historikerne på faktorer de mener vippet militærbalansen i Israels favør. Allerede i I947 mente britene at de jødiske styrkene ville bli for sterke for de palestinske araberne. ${ }^{8}$ Dette synet skulle også dominere blant palestinerne selv, blant arabiske observatører, og innenfor deler av sionistbevegelsen i Palestina. ${ }^{9}$ Til tross for det åpenbare demografiske overtaket (I,3 millioner palestinere og 650000 jøder bodde i området da krigshandlingene brøt ut) sto palestinerne dårlig rustet til å stå imot sionistene i kampen for herredømmet over landet.

Sammenlignet med palestinerne sto sionistene sterkere både politisk og militært i perioden som ledet opp til krigen. Helt siden Folkeforbundets godkjenning av det britiske mandatet for Palestina i I922, jobbet sionistene målrettet for å etablere et godt organisert og tydelig lederskap med statslignende strukturer i ryggen. Det palestinske politiske liv var til sammenligning preget av indre stridigheter, svakt lederskap og mangel på administrative strukturer som kunne ha dannet grunnlaget i en fremtidig selvstendig stat. ${ }^{\text {10 }}$ En splittet nasjonalistbevegelse ble ytterligere svekket gjennom det arabiske opprøret i perioden I936-39. ${ }^{\text {II I }}$ kontrast til rammene for sionistenes institusjonsbygging hadde 
ikke britene tillatt etablering av tilsvarende palestinske strukturer.

Militært var sionistene organisert gjennom den jødiske undergrunnsbevegelsen Haganah og andre, mindre grupperinger som LEHI og Irgun. ${ }^{\mathrm{I} 2}$ Etablert allerede i I920 representerte Haganah kjernen i de

\section{Dette er historieskriving som ligger utenfor sionismens varme favn med hensyn til nasjonsbygging.}

jødiske styrkene som kjempet i krigen. ${ }^{\text {I3 }}$ Palestinerne hadde til sammenligning total mangel på sentralt organiserte styrker. Allerede før den offisielle krigen startet hadde en fjerdedel av den palestinske befolkningen forlatt landet. Blant dem fantes mange fra den politiske og økonomiske eliten, noe som fikk konsekvenser for både lederskap og moral. I den stadig mer voldelige konflikten med jødene satte de fleste palestinere sin lit til de omkringliggende araberstatene, og kanskje i særdeleshet kong Abdullah, i kraft av hans rolle som øverstkommanderende i Den arabiske legion.

Den sionistiske versjonen av krigsforløpet vektlegger det generelle demografiske bildet som bygger opp under forestillingen om den lille Davids kamp mot Goliat. Denne historien fremstiller den israelske hæren som militært underlegne både i form av mannskap og tilgang på våpen. De nye historikerne presenterer et alternativt narrativ som forteller om solid jødisk overtak i antall tropper i krigens første fase (I5. mai til første våpenhvile II. juni). I midten av mai I948 besto den jødiske hæren i
Palestina av omkring 35 ooo soldater, mot araberstatenes samlede tropper på rundt 25 ०००. ${ }^{\text {I4 }}$ På dette tidspunktet hadde imidlertid israelerne tilgang til militært utstyr av dårlig kvalitet, noe som var en svakhet sammenlignet med araberstatene. Innen krigens andre fase (8.-I8. juli) tok til, hadde militærbalansen definitivt vippet $\mathrm{i}$ Israels favør. Den israelske hæren hadde $\sigma_{5}$ ooo soldater, og hadde lyktes i fremstøtene for å få illegale våpenleveranser under den første våpenhvilen. ${ }^{15}$ I samsvar med Israels statsminister David Ben-Gurions strategi, angrep hæren de arabiske troppene en etter en slik at den israelske staten kunne sikres. ${ }^{16}$ Ben-Gurion oppfattet at Israels "hemmelige våpen" ikke nødvendigvis fantes i egen kampvilje, men snarere i arabernes inkompetanse. ${ }^{17}$

\section{Araberstatene: En samlet fiende?}

Ifølge den tradisjonelle sionistiske versjonen sto araberne fra første dag samlet rundt målet om å knuse den jødiske staten. En koordinert militæroffensiv skulle sikre denne målsetningen og gi araberne kontroll over Palestina. Trusselen mot den israelske staten var eksistensiell, og utfallet av krigen uventet. De nye historikerne bestrider ikke at krigen i I948 representerte en eksistensiell krise for Israel. Men i kontrast til sionistisk historiefortelling, peker deres funn mot at arabisk splittelse og Israels vilje til å utnytte denne svakheten dannet sentrale premisser for israelsk seier. $^{18}$

Arabisk militær og diplomatisk samling mot Israel i i 948 viste seg å være en myte. ${ }^{19}$ Til tross for en felles plan for invasjonen av Israel/Palestina, utarbeidet av Den arabiske liga mislyktes de arabiske lederne i å omsette planen til handling. Den I5. mai 
invaderte militærstyrker fra Egypt, Syria, Irak og Transjordan (samt to kontingenter fra Saudi-Arabia og Jemen), ${ }^{20}$ men styrkene var alt annet enn blokkorienterte. Faktorer som lange kommunikasjonslinjer, dårlig etterretning, usikkert lederskap, svak koordinering, mangelfull planlegging og interne stridigheter gjorde sitt til at en sterk koalisjon fremsto som et uoppnåelig ideal. ${ }^{21}$ Forholdet mellom de arabiske lederne på slutten av I940-tallet ga lite rom for solidaritet og avtalt spill. Forholdet mellom Transjordan og Irak på ene siden, mot Egypt og Saudi-Arabia på den andre, var preget av rivalisering og splittelse. I fokus sto kampen om regional dominans. ${ }^{22}$ Ideen om en felles sak ble sterkt svekket av kong Abdullah av Transjordan og hans planer om å realisere drømmen om et StorSyria - på palestinernes og andre nabostaters bekostning. Land som Syria, Libanon, Egypt og Saudi-Arabia så alle på kong Abdullah med stor skepsis. ${ }^{23}$ Mens Syria og Libanon fryktet at Abdullahs planer ville bety slutten for deres unge stater, forsøkte Egypt og Saudi-Arabia å vokte sine ledende posisjoner i Midtøsten.

Helt siden opprettelsen av Transjordan, som ble delt fra det øvrige mandatet for Palestina i I92I, hadde det eksistert kontakt mellom kong Abdullah og sionistene. ${ }^{24}$ Noen dager før offentliggjøringen av FNs delingsplan hadde kongen et hemmelig møte med Golda Meyerson (Meir), den gang representant for Det jødiske byrå i Palestina. Selv om resultatet av møtet ikke ble en formell nedtegnet avtale, hevder den nye historikeren Avi Shlaim at det var bred enighet mellom partene. ${ }^{25}$ I praksis gikk denne enigheten ut på at sionistene og den transjordanske kongen skulle dele Palestina mellom seg. For sionistene var det viktig at kong Abdullah i så stor grad som mulig kunne virke som en brems, ikke bare på de andre araberstatene, men også på de offensive målsetningene for Den arabiske legion, den mest profesjonelle militærstyrken i regionen. Forståelsen mellom Abdullah og sionistene ble satt under press fra araberstatene, som fryktet at hashemittkongen sto i ledtog med fienden. Dette presset, i kombinasjon med strømmen av palestinske flyktninger som kom over grensen til Transjordan, skulle føre til at kongen valgte å ta del i den planlagte arabiske invasjonen av Israel. Gjennom et nytt møte med Golda Meir ıo. mai I948 ga han imidlertid uttrykk for et ønske om fortsatt kontakt med sionistene. ${ }^{26}$ Under dekke av sin ledende rolle blant araberne kunne Abdullah fortsette arbeidet for en deling av Palestina - stikk i strid med Den arabiske ligas uttalte mål, men i samsvar med hans egne, og sionistenes, ambisjoner. $^{27}$

\section{Det palestinske flyktningproblemet}

Den mest betente konflikten mellom "gammel" og "ny" israelsk historie omhandler det palestinske flyktningproblemet. Sammen med selve opprettelsen av staten Israel, ble begynnelsen på flyktningproblemet den viktigste politiske konsekvensen av krigen i i948. Etter krigens slutt ble det anslått at 600 ooo-760 ooo palestinere hadde flyktet over grensene til de omliggende araberstatene. ${ }^{28}$ Sionistisk historiefortelling har behandlet flyktningproblemet som et resultat av palestinernes frivillige flukt fra landet, gjerne etter oppfordring fra arabiske ledere lokalt eller regionalt.

De nye historikernes funn forteller en annen historie om flyktningproblemets 
opprinnelse. I ny israelsk historie pekes det spesielt på krigens indre dynamikk, sammenhengen mellom jødiske og, etter hvert, israelske militære offensiver og masseflukten, samt mangelen på et samlende palestinsk lederskap. Arbeidene til Benny Morris er sentrale; hans detaljerte studier av utviklingen i Palestina, fra offentliggjør-

\section{Med unntak av Benny Morris er de nye historikerne marginalisert $i$ israelsk utdanningssammenheng.}

ingen av FNs delingsplan, 29. november I947, til perioden etter krigens slutt, bygger på dokumenter fra israelske arkiver. ${ }^{29}$ Likevel ligner historien Morris bringer frem i lyset lite på fremstillingen som i årtier dominerte israelsk historieberetning og offentlig bevissthet. Ifølge Morris forlot palestinske flyktninger sine hjem i etapper, der tidspunktene for flyktningstrømmene hang direkte sammen med krigføringen på bakken. ${ }^{30}$

Grunnlaget for flyktningproblemet ble lagt allerede før krigen tok til. Tiden etter offentliggjøringen av FNs delingsplan var preget av harde kamper mellom den jødiske undergrunnsbevegelsen, palestinske irregulære styrker og frivillige krigere fra andre araberstater. I perioden desember I947 til mars I948 forlot store deler av den palestinske eliten landet, noe som svekket den nasjonale motstanden. ${ }^{3 \mathrm{I}}$ Mange landsbyer langs kysten ble også forlatt. I denne perioden, før den offisielle krigen tok til, mottok palestinere i enkelte områder oppfordringer fra lokale ledere om å forlate sine hjem. Denne oppfordringen gjaldt i fremste rekke kvinner, barn, eldre og syke. Likevel, de fleste flyktet av frykt for kampene, fremtiden og egen sikkerhet, samt på bakgrunn av økende sosial og økonomisk nød. ${ }^{22}$

Fra mars I948 blir mønsteret mellom jødiske militære offensiver og flyktningstrømmene tydelig, ifølge Morris. Jødiske angrep på palestinske byer og landsbyer utløste panikk som spredte seg raskt. Måneder med følelser av frykt, isolasjon og sårbarhet kulminerte i masseflukt. Ulike områder ble utsatt for ulik taktikk fra jødenes side. Noen palestinske samfunn ble i forkant av militære angrep utsatt for psykologisk krigføring gjennom "hviskekampanjer" om kommende kamphandlinger. I andre tilfeller ble palestinske landsbyboere regelrett drevet ut av de jødiske styrkene. ${ }^{33}$

Bruk av utdrivelsestaktikk mot palestinerne økte i omfang tett oppunder oppstarten av den offisielle krigen i midten av mai I948. Også mot slutten av krigen ble slik taktikk benyttet. Taktikken var nedfelt i Plan D, en militærplan som sionistlederne mente skulle sikre staten i tilfelle angrep fra de arabiske nabostatene. Plan D gikk i korthet ut på å rense områder for fiendtlig innstilte befolkningsgrupper, det vil si palestinere, og gjennom dette etablere "territoriell kontinuitet mellom jødiske befolkningssentra og sikre den fremtidige statens grenser før, og i påvente av, invasjonen." ${ }^{34}$ Planen ble satt i verk fra begynnelsen av april ı948, og i tråd med denne ble tusenvis av palestinere drevet fra sine hjem. I mange tilfeller "slapp" de jødiske styrkene oppgaven; rykter om utrenskninger andre steder, samt massakre som Deir Yassin 9. april I948, hvor I00-I20 palestinske landsbyboere ble drept, skapte frykt og panikk. ${ }^{35}$ 
av mange israelere oppfattet som det første tilfellet av israelsk angrepskrig og skapte brister i deres forestillinger om at landets konflikter alltid var påtvunget av araberstatene. Regjeringen, med det høyreorienterte Likud i spissen, forsøkte på sin side i liten grad å legge skjul på krigens offensive målsetninger. En stadig mer kritisk opinion mot konflikten i Libanon ble ytterligere forsterket gjennom starten på det palestinske opprøret mot israelsk okkupasjon i desember I987. ${ }^{38}$ Døren inn mot større grad av selvkritikk var åpnet, og det var inn i dette rommet de nye historikerne trådte.

Den viktigste faktoren for omskrivingen av I948 er likevel den liberale arkivlovgivningen i Israel. Etter at Likud kom til makten i I977 ble israelske myndigheter gradvis mer åpne i forhold til krigen i i948. I motsetning til venstresiden $\mathrm{i}$ israelsk politikk, fryktet ikke høyresiden større grad av åpenhet rundt jødenes kamp for Palestina før, under og etter krigen. I I98I ble den israelske arkivloven endret og en trettiårsregel på frigjøring av dokumenter innført. Gjennom denne endringen fikk forskere tilgang til store mengder statsdokumenter som tidligere hadde vært unndratt offentligheten. Historikere som ønsket å skrive om krigen i i948 fikk dermed et helt annet kildegrunnlag for sin forskning. Basert på de senest tilgjengelige kildene om hendelsene forbundet med krigen viste det seg også lettere å bevege seg vekk fra den propagandistiske stilen som hadde dominert israelsk historiefortelling.

\section{Kilde til konflikt}

De nye historikerne har vært, og er, en kilde til høylytt diskusjon og konflikt. Inntil de trådte frem i det offentlige rom forholdt den jevne israeler seg stort sett til en for- telling om I948 i nasjonalistiske farger. Deri ligger en forklaring på hvorfor de nye historikerne er blitt møtt med hissige angrep fra akademikere, politikere og andre meningsbærere i det israelske samfunnet. Selv har de på ingen måte stått på sidelinjen når kritikken har haglet. De har tvert imot kastet seg inn i diskusjonene og heller ikke gått av veien for å kritisere hverandre - i til tider sterke ordelag. ${ }^{39}$

Debattens omfang og temperatur gienspeiler dybden i temaene som er blitt problematisert. Fremfor alt har debatten om I948 vært synlig på to arenaer, nemlig akademikere imellom og innenfor det israelske kollektivet - som ett folk med felles historie og ansvar. På den første arenaen er det blitt ført kritikk fra akademikere både som profesjonelle aktører innenfor et yrke, og som maktelitens målbærere og støttespillere. På den andre arenaen er det israelere som kollektiv enhet og deres forståelse av egen historie og rolle $\mathrm{i}$ fortid og nåtid, som står i sentrum.

\section{Historikerfeiden}

En rekke akademikere, både i og utenfor Israel, har rettet hard kritikk mot de nye historikerne. I den akademiske debatten strides det om gjengivelse, fortolkning og plassering av hendelser basert på tilgjengelig primærmateriale. Hvilke kilder som skal tillegges vekt er et kjernepunkt i denne diskusjonen. De nye historikernes begrensede bruk av arabiske kilder kan påpekes som en åpenbar svakhet, idet det gir israelske og britiske kilder stor vekt. ${ }^{40}$ Enkelte kritikere går imidlertid mye lengre og det finnes de som simpelthen benekter validiteten av de nye historikernes funn. ${ }^{4{ }^{\mathrm{T}}}$ Andre anklager dem for å bruke sin posisjon til å fremme en politisk agenda. ${ }^{42}$ Det 
er også blitt gjort forsøk på å avlede oppmerksomheten fra historikernes funn ved å anklage dem for å være selvhatende jøder og svikere. ${ }^{43}$ Slik blir diskusjonen om

\section{Paradoksalt nok retter beskyldninger} om politisk motivert akademisk produksjon søkelyset mot kritikernes egne ideologiske hensyn.

omskrivingen av I948 gjort personlig, fjernet fra rammene og reglene i en akademisk debatt. Paradoksalt nok retter beskyldninger om politisk motivert akademisk produksjon søkelyset mot kritikernes egne ideologiske hensyn. Beskyldningene belyser historikernes rolle der de effektivt binder fortid og nåtid sammen og slik kan bidra til utforming, eller vedlikehold av kollektiv identitet. ${ }^{44}$ Som seierherrenes verktøy er historie nyttig i en nasjonsbyggingsfase. Det er derfor lite overraskende at ny israelsk historie er spesielt upopulær blant den eldre garde av Mapai (nå en del av det israelske Arbeiderpartiet) og deres meningsfeller innenfor akademia. Konfrontert med ny historie dukker behovet for å opprettholde egen posisjon og renommé opp. Personlig følelsesmessig engasjement, enten gjennom faktisk deltagelse $\mathrm{i}$ krigen, tydelige minner fra I948, eller posisjon knyttet til nettverk assosiert med den gamle makteliten er dermed noen av faktorene som kan forklare den skarpe kritikken.

\section{Identitetskrisen}

Debatten som fulgte i kjølvannet av de nye historikernes publikasjoner beveget seg raskt fra akademiske kretser til den bredere offentligheten. Omskrivingen av krigen i I948 utfordret ikke bare den gamle makteliten og deres støttespillere, men også Israels kollektive hukommelse. Kollektiv hukommelse kan forstås som rekonstruksjon og fortolkning av fortiden i lys av nåtidens kunnskap og behov. ${ }^{45}$ I tråd med rådende maktstrukturer, eller etter nytteverdiprinsipp kan historiske hendelser bli gitt ny mening og relevans, ofte fjernet fra funn gjennom historisk forskning. Politiske ledere står i posisjon til å benytte muligheten til å tolke og bruke historien som redskap og slik gi den farge av gjeldende interesser. ${ }^{46}$

Myter var et viktig redskap i tiden som fulgte den israelske statsdannelsen. En ny identitet skulle formes innenfor rammene av den nye nasjonalstaten, og prosjektet involverte integrasjon av hundretusener av immigranter med svært ulik bakgrunn. Selektiv bruk av historie fikk en viktig funksjon, en trend som i seg selv ikke er særegen for Israel. Hvilke lærebøker som godkjennes for bruk i grunnskolen, hvilke begivenheter som markeres nasjonalt, og hvordan politikere og andre meningsbærere omtaler historien i offentligheten danner grunnlaget for hvordan en borger oppfatter historien om hva som har skjedd og hvordan det skjedde.

Bildet som ble tegnet av I948, fant sitt fokus i krigens første fase. Denne fasen var karakterisert av stor usikkerhet blant jødene i Palestina som følte seg isolert, sårbare og underlegne i forhold til araberstatene. Den israelske kollektive hukommelsen av I948 fikk preg av opplevelser i denne traumatiske perioden fremfor pilene som raskt pekte i retning av israelsk seier. ${ }^{47}$ Den sionistiske historiefortellingen hadde verken 
rom for alternative fremstillinger av fienden eller kritikk av sionistenes handlinger. Nettopp derfor er de nye historikernes funn for enkelte blitt oppfattet som et direkte angrep på nasjonale helligdommer, selve grunnlaget for israelsk identitet.

Forskjellen som oppsto mellom tidligere etablerte sannheter og ny historiefortelling, utfordret israelsk selvforståelse. Myteknekkerne ga en ny versjon av fortiden som utvisket deler av skillet mellom Israel som uskyldig offer, og araberstatene som en krigstørst overmakt. Bildet av palestinerne som ofre for krigen, satte spørsmålstegn ved sionistenes fremferd og knyttet fortidens hendelser sammen med samtidens politiske realiteter. Slik førte de nye historikerne Israel inn i en identitetskrise preget av spørsmål som "Hvem er vi?”, "Hva er vår historie?”, og "Hvor går vi?". $4^{8}$ Grunnlaget for israelsk kollektiv identitet ble med andre ord problematisert, innenfor nye rammer. En åpen diskusjon rundt disse spørsmålene er vanskelig, ikke minst for etablerte maktstrukturer og personer, hvis posisjon er bundet til de gamle forestillingene.

Med de nye historikernes tilsynekomst måtte den hegemoniske sionistiske versjonen vike for mer pluralistisk tankegang rundt Israels historie og kollektive selvforståelse. ${ }^{49}$ Ny historiefortelling viser bindingene mellom det sionistiske statsprosjektet og det palestinske flyktningproblemet. For enkelte kritikere er denne problematiseringen av sionismen i seg selv spesielt vanskelig å håndtere. For dem blir de nye historikernes fremstilling av I948 oppfattet som et forsøk på å undergrave sionismen, statens legitimitet og fremtid. Med Derek Penslars ord:
"No nation can retain its basic vitality if its entire historical narrative comes to be seen in the public mind as a long series of moral failings compounded by errors of judgement." ${ }^{\circ \circ}$

Til forskjell peker den israelske utdanningsministeren Yuli Tamir på frykten som en begrensende faktor:

"[There is] a real fear to deal with the reality of a complex society, which has at least two narratives. There's a lot of tension, and the fact that we don't talk about it doesn't make the tension or the conflict go away." ${ }^{11}$

\section{Tilbake til marginene?}

Gjennom sine publikasjoner brøt de nye historikerne utvilsomt et tabu rundt israelsk forståelse av palestinerne og deres sak. Dette er særlig synlig i spørsmålet om det palestinske flyktningproblemet som ble fremstilt i nytt lys i den israelske offentligheten. ${ }^{52}$ Selv om andre hadde fremsatt lignende konklusjoner på et mye tidligere tidspunkt, var det først innenfor rammene av det israelske samfunnet fra slutten av I980-tallet at en bredere debatt om krigen i I948 viste seg mulig. 53

Til tross for debatten som raste har virkningene med hensyn til offentlig kunnskapsoverføring vist seg å være relativt små. Med unntak av Benny Morris er de nye historikerne marginalisert i israelsk utdanningssammenheng. Både Avi Shlaim og Ilan Pappé underviser ved universitet i Storbritannia; sistnevnte i det som nærmest kan kalles en blanding av selvvalgt og påtvunget eksil. ${ }^{54}$ Myndighetene har på sin side vist seg avventende og til tider svært negative til de nye historikernes arbeid. Endringer i undervisningsmateriell på slutten av I990-tallet i tråd med ny hist- 
orie har blitt trukket tilbake, og nye forslag om endringer har i den senere tid blitt nedstemt av israelske politikere. ${ }^{55}$

I dag ligger mange israeleres kunnskap om krigen i I948 utenfor rammene av nasjonalistisk historiefortelling. Historikerfeiden og identitetskrisen i kjølvannet av ny israelsk historie skapte nye målbærere og større rom for alternative fremstillinger. Likevel kan det sies at israelere flest har begrenset forståelse for palestinernes historie knyttet til krigen. Akkurat som historiefortelling knytter fortid og nåtid sammen har mangelen på forståelse til tross for kunnskap nær forbindelse til samtidens problematikk i Israel-Palestina konflikten. Den andre palestinske intifadaen har skapt fornyet mistillit; i den israelske konteksten dominerer på nytt oppfatningen av Israel som offer og palestinerne som fienden.

Et oppgjør med I948 vil imidlertid være nødvendig om israelere og palestinere skal kunne inngå en varig fredsavtale. Et minstekrav for palestinerne er en form for innrømmelse av skyld fra israelsk hold med referanse til det palestinske flyktningproblemet. Holdningen til og behandlingen av de nye historikernes funn er dermed av direkte relevans for fremtidens forhold mellom Israel og palestinerne. Dette understreker den viktige rollen de nye historikerne har spilt og fremdeles spiller i den israelske offentligheten. Akademiske og offentlige stridigheter til tross: Ny israelsk historie er kommet for å bli.

\section{- $f \cdot$}

I Shlaim, Avi: “The Debate about I948" i Ilan Pappé (Red.) «The Israel/Palestine Question». Routledge, London og New York 1999, s. 18I. (Forfatters oversettelse.)

2 Benny Morris var den første til å bruke betegnelsen "nye historikere" om seg selv og noen av sine historikerkollegaer i en artikkel publisert i november 1988. Morris,
Benny: "The New Historiography: Israel Confronts Its Past" i Tikkun, vol. 3, no. 6, I988.

3 Pappé, Ilan: «The Ethnic Cleansing of Palestine». Oneworld, Oxford 2006; Morris, Benny: «The Birth of the Palestinian Refugee Problem Revisited». Cambridge University Press, Cambridge.

4 Loos, Baudouin: "An Interview of Ilan Pappé". Le Soir, Brussel, 29. november 1999. (http://www.ee.bgu.ac.il/ censor/katz-directory/\$99-II-29loos-pappe-intervi ew.htm)

5 Dette danner grunnlaget for merkelappen "post-sionister" som også brukes i omtale av de nevnte historikerne.

6 Simha Flapans bok «The Birth of Israel: Myths And Realities», utgitt allerede i I987, tok også for seg sionistisk historiefortelling og mytene om I948. Flapan blir av mange ansett som "ny historiker". Hans arbeid er utelatt fra denne artikkelen med bakgrunn $i$ hans generasjonstilhørighet (f. I9II) og virke som politiker.

7 Morris, Benny: “The New Historiography: Israel Confronts Its Past" i Tikkun, vol. 3, no. 6, I988.

8 Morris, Benny: «The Birth of the Palestinian Refugee Problem Revisited. Cambridge University Press, Cambridge 2004, s. 33 .

9 Morris, Benny: «The Birth of the Palestinian Refugee Problem Revisited. Cambridge University Press, Cambridge 2004 , ss. 32-33.

Io Morris, Benny: «I948 and After: Israel and the Palestinians». Clarendon Press, Oxford I990, S. 2I.

II Khalidi, Rashid: "The Palestinians and I948: The Underlying Causes of Failure" i Eugene L. Rogan og Avi Shlaim (red.) «The War for Palestine. Rewriting the History of I948». Cambridge University Press, Cambridge 200I, ss. 26-29.

I2 LEHI (Lohamai Herut Yisrael) var en jødisk militær undergrunnsbevegelse etablert i I940. Irgun (Irgun Zva'i Leumi) ble opprettet i I93I. Begge organisasjonene utførte en rekke angrep mot britiske og palestinske mål. Medlemmer av Irgun sto bl.a. bak massakren i Deir Yassin.

I3 Morris, Benny: «I948 and After: Israel and the Palestinians». Clarendon Press, Oxford I990, S. I5.

I4 Shlaim, Avi: «The Iron Wall: Israel and the Arab World». Penguin Books, London 2000 (200I), s. 35.

I5 Shlaim, Avi: "The Debate about I948" i Ilan Pappé (red.) «The Israel/Palestine Question». Routledge, London og New York I999, ss. I80-I8I.

I6 Shlaim, Avi: «The Iron Wall: Israel and the Arab World». Penguin Books, London 2000 (200I), s. 36

I7 Morris, Benny: 1948: «A History of the First Arab-Israeli War». Yale University Press, New Haven 2008, ss. 287289 . 
I8 Shlaim, Avi: «The Iron Wall: Israel and the Arab World». Penguin Books, London 2000 (200I), ss. 35-36.

I9 Shlaim, Avi: "Israel and the Arab Coalition in I948" i Eugene L. Rogan og Avi Shlaim (red.) «The War for Palestine. Rewriting the History of I948». Cambridge University Press, Cambridge 200I, s. 80.

20 Libanon deltok også i krigen men var ikke en del av invasjonsstyrkene. Morris, Benny: «I948: A History of the First Arab-Israeli War». Yale University Press, New Haven 2008, ss. 258-260.

2I Shlaim, Avi: "Israel and the Arab Coalition in 1948" i Eugene L. Rogan og Avi Shlaim (red.) «The War for Palestine. Rewriting the History of 1948 . Cambridge University Press, Cambridge 200I, s. 8I.

22 Shlaim, Avi: "Israel and the Arab Coalition in 1948" i Eugene L. Rogan og Avi Shlaim (red.) «The War for Palestine. Rewriting the History of 1948 . Cambridge University Press, Cambridge 200I, s. 82.

23 Shlaim, Avi: «The Iron Wall: Israel and the Arab World». Penguin Books, London 2000 (2001), s. 36.

24 Shlaim, Avi: «The Politics of Partition. King Abdullah, the Zionists and Palestine I92I-I95I». Oxford University Press, Oxford I988 (2004), s. 42.

25 Shlaim, Avi: «The Iron Wall: Israel and the Arab World». Penguin Books, London 2000 (200I), s. 30.

26 Shlaim, Avi: "Israel and the Arab Coalition in 1948 " i Eugene L. Rogan og Avi Shlaim (red.) «The War for Palestine. Rewriting the History of I948. Cambridge University Press, Cambridge 200I, ss. 87-88.

27 Den arabiske liga avviste FNs delingsplan i et enstemmig vedtak og motsatte seg planene om en jødisk stat i Palestina.

28 Morris, Benny: «The Birth of the Palestinian Refugee Problem. Cambridge University Press, Cambridge 1987 (1989), s. I.

29 Morris, Benny: «The Birth of the Palestinian Refugee Problem, I947-I949». Cambridge University Press, Cambridge 1987; «I948 and After: Israel and the Palestinians». Clarendon Press, Oxford I990; «The Birth of the Palestinian Refugee Problem Revisited». Cambridge University Press, Cambridge 2004; «I948: A History of the First Arab-Israeli War». Yale University Press, New Haven 2008.

30 Morris, Benny: «The Birth of the Palestinian Refugee Problem Revisited». Cambridge University Press, Cambridge 2004 , s. 590 .

3I Morris, Benny: I948: «A History of the First Arab-Israeli War». Yale University Press, New Haven 2008, s. 94.

32 Morris, Benny: «The Birth of the Palestinian Refugee Problem Revisited. Cambridge University Press, Cambridge 2004 , s. 590 .

33 Morris, Benny: «The Birth of the Palestinian Refugee Problem Revisited. Cambridge University Press, Cam- bridge 2004 , ss. 59I-592.

34 Morris, Benny: «The Birth of the Palestinian Refugee Problem Revisited. Cambridge University Press, Cambridge 2004, s. I64. (Forfatters oversettelse.)

35 Morris, Benny: «The Birth of the Palestinian Refugee Problem Revisited. Cambridge University Press, Cambridge 2004 , s. 238.

36 Morris, Benny: «The Birth of the Palestinian Refugee Problem Revisited. Cambridge University Press, Cambridge 2004, s. 309 .

37 Morris, Benny: «The Birth of the Palestinian Refugee Problem Revisited. Cambridge University Press, Cambridge 2004 , s. 589 .

38 Levy, Daniel: "The Future of the Past: Historiographical Disputes and Competing Memories in Germany and Israel" i History and Theory, vol. 38, no. I, I999, s. 59.

39 Et eksempel på ulikhetene og diskusjonene innad blant de nye historikerne er Avi Shlaims kritikk av Benny Morris. Se Morris, Benny: "Peace? No Chance" i The Guardian, London 2I. februar 2002; Shlaim, Avi: "A Betrayal of History" $\mathrm{i}$ The Guardian, London 22. februar 2002; Katz, Ian: "Radical Israeli in U-turn on Palestinians" $i$ The Guardian, London 3. oktober 2002; intervju med Avi Shlaim "No Peaceful Solution" i Ha'aretz Friday Supplement, Tel Aviv II. august 2005.

40 Restriktiv arkivpolitikk i de arabiske landene involvert i krigen er en viktig grunn til ubalansen i kildebruk. Relevant materiale fra statsarkivene i land som Egypt, Jordan, Syria, Irak og Libanon er fremdeles utilgiengelig. Se Rogan, Eugene L. og Shlaim, Avi (Red.) «The War for Palestine. Rewriting the History of 1948». Cambridge University Press, Cambridge 200I (2007), s. 6.

4I Den israelske historikeren Efraim Karsh har over tid ledet an kritikken mot de nye historikerne. Se Karsh, Efraim: «Fabricating Israeli History: The 'New Historians'». Frank Cass, London 1997 (2000).

42 Teveth, Shabtai: "Charging Israel with Original Sin" i Commentary, 88: september I989; Gutwein, Daniel: “Left and Right Post-Zionism and the Privatization of Israeli Collective Memory" i Anita Shapira og Derek J. Penslar (red.) «Israeli Historical Revisionism: From Left to Right». Frank Cass, London 2003.

43 Bronner, Ethan: "The New New Historians" i The New York Times, New York 9. november 2003.

44 Levy, Daniel: "The Future and the Past: Historiographical Disputes and Competing Memories in Germany and Israel" i History and Theory, vol. 38, no. I, I999, ss. 5I-52.

45 Halbwachs, Maurice: «On Collective Memory» (redigert, oversatt og med innledning av Lewis A. Coser). University of Chicago Press, London 1992.

46 Zertal, Idith: «Israel's Holocaust and the Politics of Nationhood». Cambridge University Press, Cambridge 2005 , s. 23.

47 Shlaim, Avi: "Israel and the Arab Coalition in 1948" i 
Eugene L. Rogan og Avi Shlaim (red.) «The War for Palestine. Rewriting the History of I948». Cambridge University Press, Cambridge 200I, ss. 89-90.

48 Silberstein, Laurence J.: «The Postzionism Debates: Knowledge and Power in Israeli Culture. Routledge, New York og London I999, s. 2.

49 Levy, Daniel: "The Future and the Past: Historiographical Disputes and Competing Memories in Germany and Israel" i History and Theory, vol. 38, no. I, I999, s. 6I.

50 Penslar, Derek: "Making History" i Azure, Spring 5760/ 2000 , s. I6.

5I Waldoks, Ehud Zion og Rettig, Haviv: “'Nakba' to Stay Out of School Curriculum" i Jerusalem Post Online Edition, 6. november 2007.

52 Hirsch, Michal Ben-Josef: "From Taboo to Negotiable: The Israeli New Historians and the Changing Representation of the Palestinian Refugee Problem" i Perspectives on Politics, vol. 5, no. 2, 2007, s. 24I.

53 Allerede på I950-tallet ble det utgitt bøker med lignende materiale, dog basert på andre typer kilder. Avnery, Uri: «HaTsad HaSheni shel HaMatbea» [The Other Side of the Coin], Tel Aviv I950; Schechtman, Joseph B.: «The Arab Refugee Problem». Philosophical Library, New York 1952; Gabbay, Rony E.: «A Political Study of the Arab-Jewish Conflict: The Arab Refugee Problem (A Case Study)». Minard, Paris I959.

54 Negev, Ayelet: “Ilan Pappé: I'm not a Traitor" i Yediot Aharonot (www.ynetnews.com) I5. mars 2008. (http:// www.ynetnews.com/articles/0,7340,L-3516I93,00.html)

55 Rogan, Eugene, L. og Shlaim, Avi: (Red.) «The War for Palestine. Rewriting the History of I948». Cambridge University Press, Cambridge 200I (2007), s. xxi-xxii Julian, Hana Levi og Fendel, Hillel: "Israel Education Ministry 'Nakba' Curriculum” i Arutz Sheva - IsraelNational News.com, 22. juli 2007; Waldoks, Ehud Zion og Rettig, Haviv: "Nakba' to Stay Out of School Curriculum" i Jerusalem Post Online Edition, 6. november 2007. 